\title{
Constitution and properties of ceramized fireclay refractories: I. Constitution
}

\author{
S P CHAUDHURI* and B K BHAUMIK \\ Special Ceramics Section, Central Glass and Ceramic Research Institute, Calcutta 700 032, India \\ MS received 29 July 1996; revised 7 June 1997

\begin{abstract}
A poor-grade fireclay was mixed with three nucleating agents, namely $\mathrm{Cr}_{2} \mathrm{O}_{3}$, $\mathrm{V}_{2} \mathrm{O}_{5}$ and $\mathrm{TiO}_{2}$. The fireclay and oxide mixed fireclay were fired at $1300^{\circ} \mathrm{C}$ for $1 \mathrm{~h}$, cooled down to room temperature and then heat-treated at $1150^{\circ} \mathrm{C}$ for $15 \mathrm{~h}$. These were also heat-treated at $1150^{\circ} \mathrm{C}$ for $15 \mathrm{~h}$ after cooling down to $1150^{\circ} \mathrm{C}$ from the peak temperature. The heat-treatment caused ceramization of the glassy phase in the fireclay samples, and the samples, mineralogical composition and microstructure were investigated. Ceramization brought about significant changes in the microstructure only.
\end{abstract}

Keywords. Fireclay; ceramization: constitution: properties.

\section{Introduction}

The fireclay refractories consist of three main phases, i.e. mullite and quartz are the crystalline components and glass is the amorphous portion. The amount of each phase is dependent on the $\mathrm{Al}_{2} \mathrm{O}_{3}, \mathrm{SiO}_{2}$ and flux content of the fireclay. A good-grade fireclay, which contains high $\mathrm{Al}_{2} \mathrm{O}_{3}$ and low alkalis/alkaline earths, yields more crystals, particularly mullite, than glass (McGee 1966). But the reverse is observed in a poorgrade (low $\mathrm{Al}_{2} \mathrm{O}_{3}$ and high alkalis/alkaline earths) fireclay.

This glassy phase has the chemical composition (Chaudhuri and Dutta 1990) which is prone to phase separation by nucleation and crystallization process (MacDowell and Beall 1969). The mullite crystals, which are thus precipitated from this large pool of glass, are submicron in size and uniformly distributed in the matrix. An improvement in the constitution of the poor-grade fireclay refractories can, therefore, be achieved by increasing the concentration of mullite crystals and thereby provide a homogeneous microstructure. Besides, glass content of such refractories may be reduced and the viscosity of the residual glass raised due to crystallization of the more aluminous crystalline phase mullite.

Ceramized fireclay refractories are, therefore, poor-grade fireclay refractories which are upgraded by the process of controlled nucleation and crystallization of their glassy phase.

A poor-grade fireclay, containing about $20 \mathrm{wt} . \% \mathrm{Al}_{2} \mathrm{O}_{3}$, was thoroughly mixed with nucleating agents and subsequently nucleated and heat-treated. The mineralogical composition and microstructure of the ceramized refractory products are presented here.

\section{Experimental}

\subsection{Characterization of raw fireclay}

Raw fireclay was collected from Purulia District of West Bengal. The deep brown clay was plastic. The constituent clay minerals, other associated phases and the particle size

*Author for correspondence 
distribution of the fireclay were identified by X-ray diffractometry, differential thermal analysis and $\mathrm{X}$-ray sedimentation method.

\subsection{Chemical and phase analyses of fireclay}

The fireclay was fired at $1300^{\circ} \mathrm{C}$ for $1 \mathrm{~h}$. The oxide constituents were estimated by the standard wet chemical procedures. The phases were identified and their concentrations determined by X-ray diffractometry (Klug and Alexander 1974) by comparison of the peak-heights of the selected reflections of the identified phase in the fireclay with those of the same phase in the standard samples. The calibration curve was drawn by plotting the peak height against the concentration of the phase in the standard samples. The estimated error of this determination was $\pm 2 \mathrm{wt} . \%$.

\subsection{Preparation of samples}

The fireclay was mixed with nucleating agents thoroughly by wet milling in a pot mill. The slurry was dried and pressed into small cubes. The cubes were then fired under three different conditions, i.e. for nucleation (i) fired at $1300^{\circ} \mathrm{C}$ for $1 \mathrm{~h}$ and then cooled down to room temperature; for crystallization (ii) fired at $1300^{\circ} \mathrm{C}$ for $1 \mathrm{~h}$, cooled down to room temperature and then heat-treated at $1150^{\circ} \mathrm{C}$ for $15 \mathrm{~h}$ and (iii) fired at $1300^{\circ} \mathrm{C}$ for $1 \mathrm{~h}$, cooled down to $1150^{\circ} \mathrm{C}$ and then heat-treated at $1150^{\circ} \mathrm{C}$ for $15 \mathrm{~h}$.

Three oxides (AR/GR grade), i.e. $\mathrm{Cr}_{2} \mathrm{O}_{3}(1.0 \mathrm{wt} . \%), \mathrm{V}_{2} \mathrm{O}_{5}(3.0 \mathrm{wt} . \%)$ and $\mathrm{TiO}_{2}$ $(10.0 \mathrm{wt} . \%)$ were used as nucleating agents. The cations of these oxides have high charge and small size $\left(\mathrm{Cr}^{3+} 0.615 \AA, \mathrm{V}^{5+} 0.540 \AA\right.$ and $\left.\mathrm{Ti}^{4+} 0.605 \AA\right)$ and are very effective for nucleation/crystallization of glass. Besides, these oxides have good structural resemblance with the precipitating mullite crystals and therefore are very efficient nucleating agents. Mullite having orthorhombic crystal system crystallizes much better on the nuclei which have closely similar crystal system as that of mullite. The $\mathrm{Cr}_{2} \mathrm{O}_{3}$, $\mathrm{V}_{2} \mathrm{O}_{5}$ and $\mathrm{TiO}_{2}$ belong to rhombohedral, rhombohedral and tetragonal (anatase), orthorhombic (brookite) crystal systems, respectively that match well with the orthorhombic system (Hulbert 1959; Wells 1962).

The solubility of $\mathrm{Cr}_{2} \mathrm{O}_{3}, \mathrm{~V}_{2} \mathrm{O}_{5}$ and $\mathrm{TiO}_{2}$ in the glassy phase dictated their concentrations to be added to the clay. The solubility of $\mathrm{Cr}_{2} \mathrm{O}_{3}$ in glass is very negligible. Among the other two oxides, $\mathrm{TiO}_{2}$ is more soluble than $\mathrm{V}_{2} \mathrm{O}_{5}$ in glass. With this point in view, $1.0 \mathrm{wt} \% \mathrm{Cr}_{2} \mathrm{O}_{3}, 3.0 \mathrm{wt} . \% \mathrm{~V}_{2} \mathrm{O}_{5}$ and $10.0 \mathrm{wt} . \% \mathrm{TiO}_{2}$ were used.

The nucleated samples were subjected to differential thermal analysis (DTA) and strong exothermic peaks were observed at $1150^{\circ} \mathrm{C}$. Since this was characteristic of crystallization of the main phase, mullite, in the samples, they were heat-treated at $1150^{\circ} \mathrm{C}$.

\subsection{Analysis of samples}

2.4a X-ray diffractometry: The samples were crushed, agated to fine powder and were subjected to X-ray diffractometry (XRD). Mullite and quartz were identified to be the only crystalline phases in the samples. Each sample was scanned in a diffractometer with $\mathrm{CuK}_{\alpha}$ radiation at the rate of $1^{\circ}(2 \theta) / \mathrm{min}$ to obtain the peaks of $1.52 \AA$ and $2.20 \AA$ 


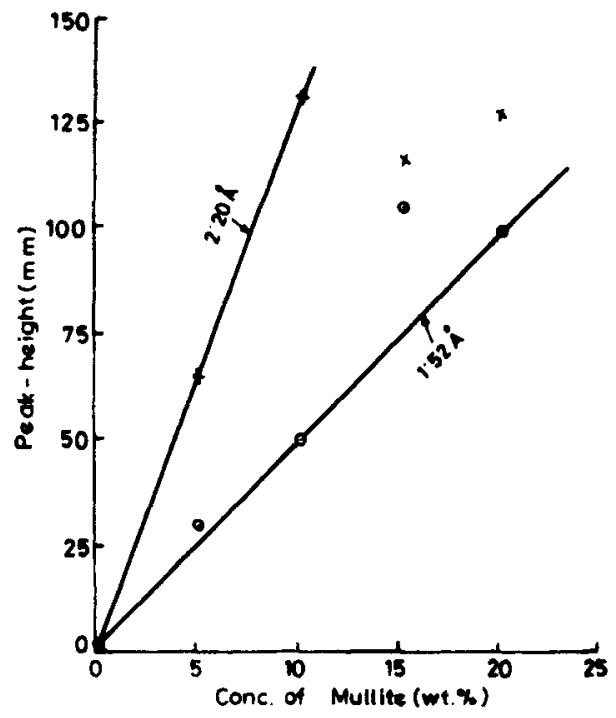

Figure 1. X-ray calibration curve for estimation of mullite.

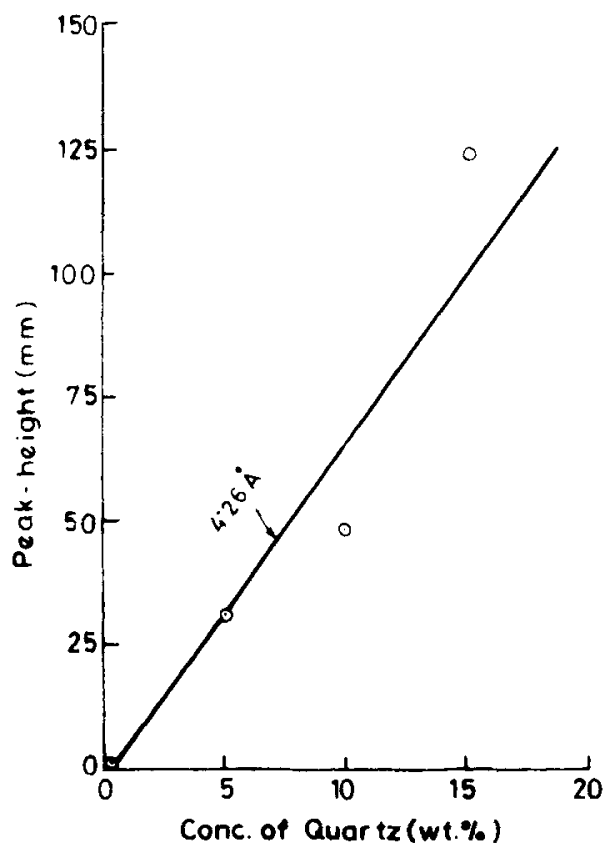

Figure 2. X-ray calibration curve for estimation of quartz.

reflections of mullite and $4 \cdot 26 \AA$ reflection of quartz. The mullite and quartz content of each sample was calculated from the calibration curve for mullite (figure 1) and that of quartz (figure 2), respectively. The remaining phase in each sample was glass. The concentration of glass in each sample was calculated by deducting the total (mullite + quartz) content from 100. The chemical composition of the glassy phase was determined on the assumption that the total concentration of all the oxides present in it (except those present in the crystalline phases) equalled to 100. 


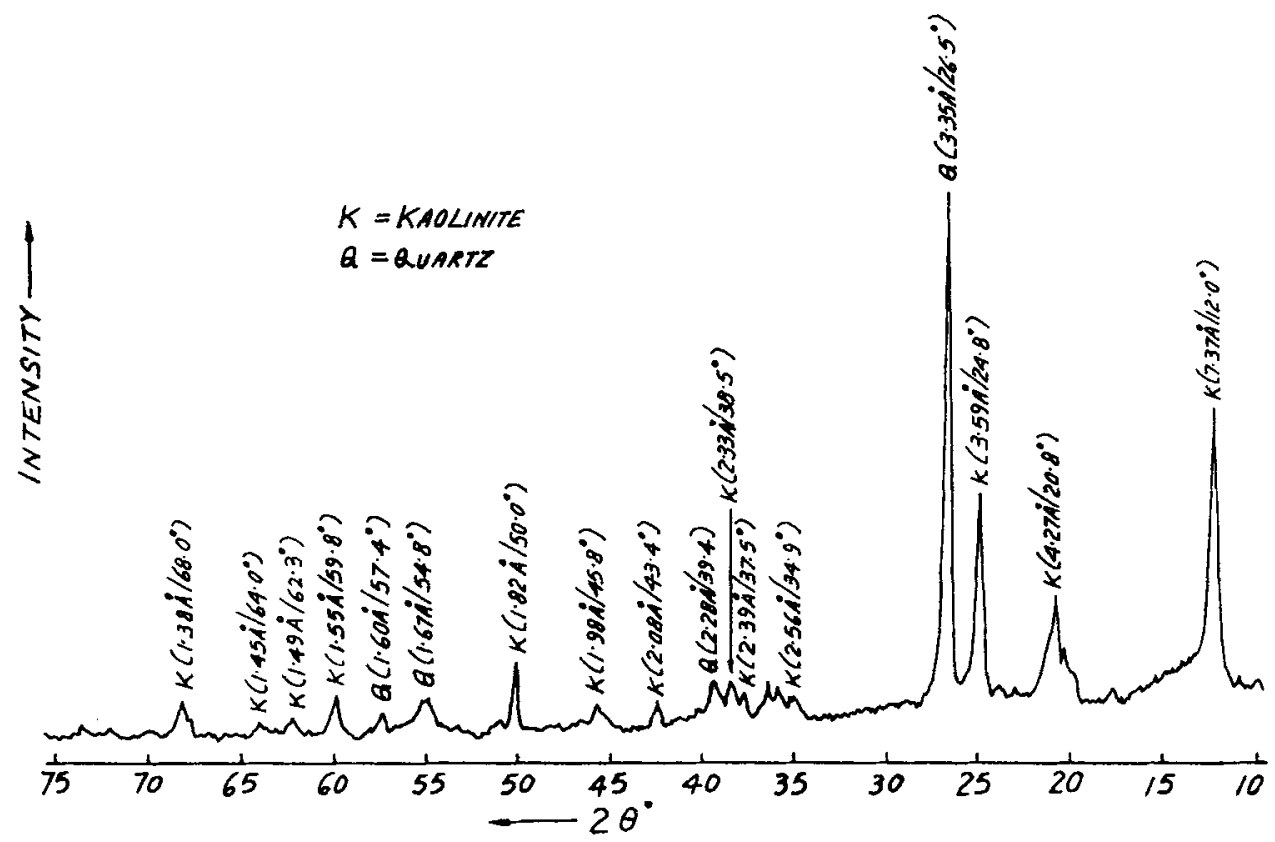

Figure 3. X-ray diffraction pattern of raw fireclay.

Table 1. Chemical analysis (wt. \%) of the fireclay fired at $1300^{\circ} \mathrm{C}$ for $1 \mathrm{~h}$.

\begin{tabular}{lccccccc}
\hline $\mathrm{SiO}_{2}$ & $\mathrm{Al}_{2} \mathrm{O}_{3}$ & $\mathrm{Fe}_{2} \mathrm{O}_{3}$ & $\mathrm{TiO}_{2}$ & $\mathrm{CaO}$ & $\mathrm{MgO}$ & $\mathrm{Na}_{2} \mathrm{O}$ & $\mathrm{K}_{2} \mathrm{O}$ \\
\hline 56.97 & 24.99 & 8.42 & 2.59 & 3.95 & 0.40 & 0.34 & 2.34 \\
\hline
\end{tabular}

2.4b Scanning electron microscopy: Each sample was fractured into small pieces. The exposed surface was etched with $40 \% \mathrm{HF}$ for $1 \mathrm{~min}$ and then coated in vacuum with a thin film of gold. Micrographs were taken from different sites of the fractured pieces in a scanning electron microscope (SEM). The crystals seen under SEM were examined by energy dispersive analysis (EDAX) attached to SEM. The peaks of Al and Si were observed.

\section{Results and discussion}

\subsection{Raw fireclay}

The characteristic reflections of kaolinite and quartz appeared in the diffractogram of the raw fireclay (figure 3). The fireclay contained kaolinite with quartz as the only associated phase. The shifting of the interplanar spacing of the basal reflection of kaolinite from $7 \cdot 15 \AA$ to $7.37 \AA$ indicated that the clay mineral kaolinite was of disordered type, having slightly defective structure. This is in conformity with the structure of fireclay. Although the existence of $\mathrm{Fe}_{2} \mathrm{O}_{3}, \mathrm{TiO}_{2}$, alkaline earths and alkalis were verified by chemical analysis of the fireclay (table 1), these were not detected by 


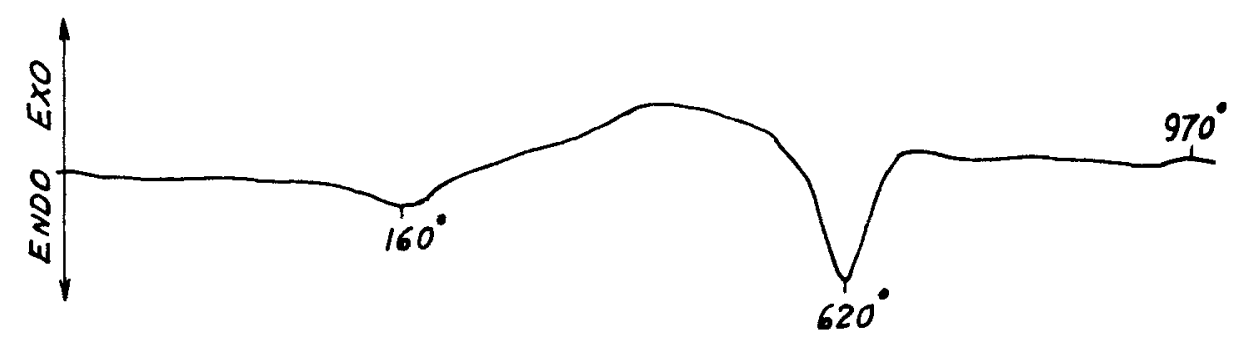

\section{TEMPERATURE ( $\left.{ }^{\circ} \mathrm{C}\right)$}

Figure 4. DTA trace of raw fireclay.

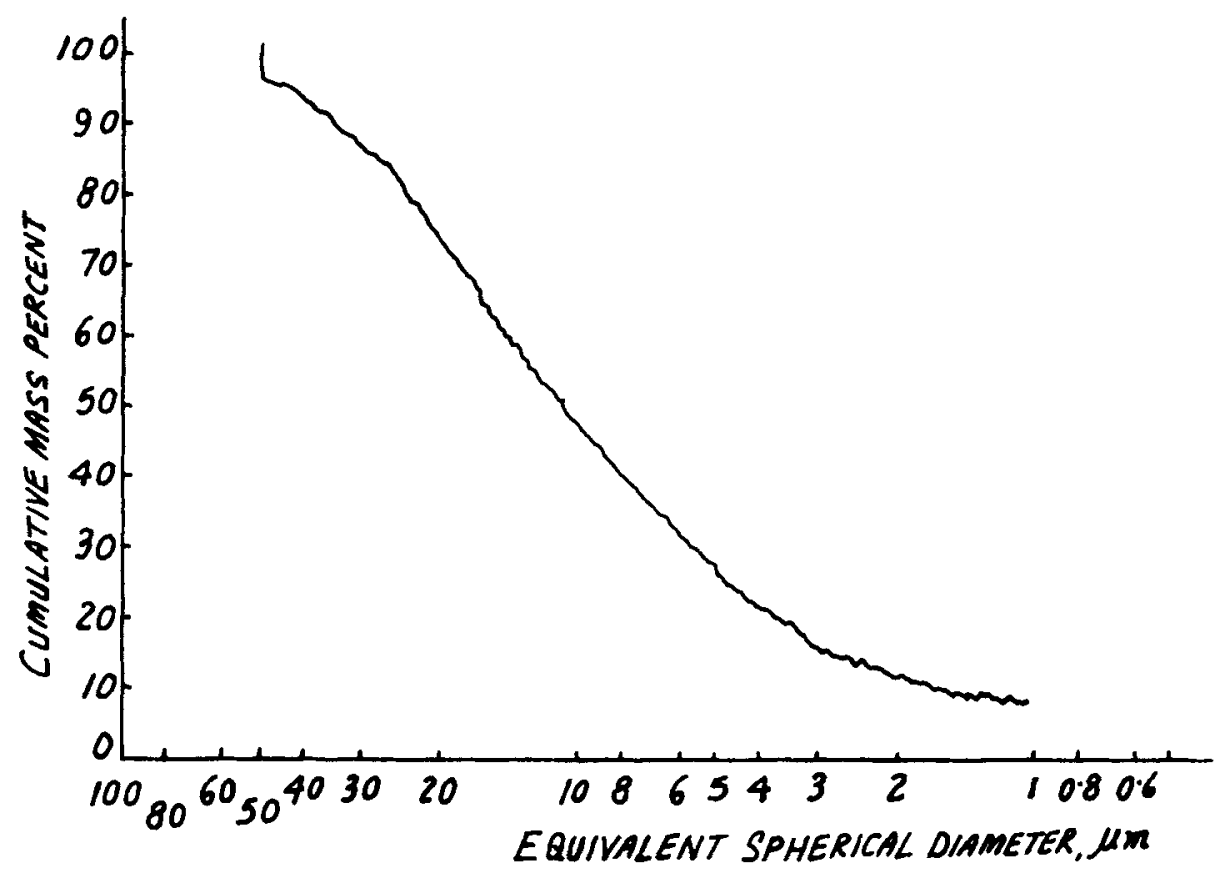

Figure 5. Particle size-distribution curve of raw fireclay.

$X$-ray analysis. These oxides were, therefore, structurally bound in the fireclay but not associated with it as mixture.

The thermogram (DTA trace) of the raw fireclay is displayed in figure 4. It is very similar to the DTA trace of kaolinite. The endothermic peaks at $160^{\circ} \mathrm{C}$ and $620^{\circ} \mathrm{C}$ corresponded to partial loss of $\mathrm{H}_{2} \mathrm{O}$ and transformation of kaolinite to metakaolinite. The small broad hump at $970^{\circ} \mathrm{C}$ was due to conversion of metakaolinite to mullite and was indicative of the disordered structure of kaolinite in fireclay. Incidentally, this exothermic peak at about $980^{\circ} \mathrm{C}$ is sharp and tall for a well-crystallized ordered kaolinite. The non-existence of the exothermic peak near $600^{\circ} \mathrm{C}$ in the thermogram may be due to the $\alpha \rightarrow \beta$ quartz conversion which is an exothermic reaction and kaolinite $\rightarrow$ metakaolinite dehydration which is an endothermic reaction that occurs simultaneously around this temperature. The expected large endothermic peak due to 
high kaolinite content in the fireclay suppressed the short exothermic peak due to small amount of quartz in it. Consequently, the exothermic peak of quartz disappeared and the endothermic peak of kaolinite was reduced.

The particle size distribution of the raw fireclay is presented in figure $5.96 \%$ of the particles were below $50 \mu$ and $8 \%$ did not exceed $1 \mu$. The average size was, however, $11 \mu$.

\subsection{X-ray diffractometry $(X R D)$}

The chemical analysis of fireclay after firing it at $1300^{\circ} \mathrm{C}$ for $1 \mathrm{~h}$ is shown in table 1 . The concentration of mullite, quartz and glassy phase as well as the composition of the glassy phase in each sample are recorded in tables 2-4.

It is calculated on the basis of chemical composition of fireclay that this could yield a maximum (theoretical) concentration of $34.5 \mathrm{wt} . \%$ mullite when fired at $1300^{\circ} \mathrm{C}$ for $1 \mathrm{~h}$. However, only $19 \mathrm{wt} \%$ mullite and $73 \mathrm{wt} . \%$ glass was obtained under this condition. It was observed in a previous work (Chaudhuri and Datta 1996a) that about $14 \mathrm{wt} . \%$ mullite could be precipitated from the synthetic glass. This is very similar to that generated in this fireclay by the process of nucleation and crystallization. Therefore, if this fireclay is incorporated with the nucleating agents and subjected to nucleation and crystallization by proper heat-treatment conditions as those employed in this study, its mullite content could have been increased by approximately $10 \mathrm{wt} . \%$ $(73 \times 0 \cdot 14=10 \cdot 22)$ over $19 \mathrm{wt} . \%$. Consequently, the total mullite content of the ceramized fireclay products would be $(19+10 \cdot 22)=29 \cdot 22 \mathrm{wt} . \%$. This amount is about $85 \%$ of the theoretical mullite content of the fireclay itself. Thus, ceramization caused an increase to about $30 \mathrm{wt} . \%$ mullite in this fireclay.

As seen from tables 2-4 the mullite content of the samples, mixed with $\mathrm{Cr}_{2} \mathrm{O}_{3}$ and $\mathrm{V}_{2} \mathrm{O}_{5}$, reached almost the limiting value and are close to each other, but addition of $\mathrm{TiO}_{2}$ caused reduction in the amount of mullite. In some cases heat-treatment caused small increase in glass content. It is important to note that there was very little difference in the concentration of mullite of the nucleated samples which were fired at $1300^{\circ} \mathrm{C}$ for $1 \mathrm{~h}$ only and also those subsequently heat-treated under the two heat treatment conditions. So, a short-time, e.g. $15 \mathrm{~h}$ of heat-treatment had apparently no influence on the mineralogical composition of the samples.

\subsection{Scanning electron microscopy}

The effect of heat-treatment on the microstructure of the samples is evident from the SEM (figures 6-9). The size of the crystal is shown by the magnification bar on the SEM micrograph. Irrespective of the lengths of the magnification bars on these micrographs, each bar represents a size equal to $1 \mu$.

The energy dispersive analysis (EDAX) of the HF-etched samples could not prove the existence of any trace second phase. The elemental analysis proved the presence of mullite only. The samples are arranged in a matrix as shown in table 5. Samples of similar composition but treated with different heating schedule are placed along the rows and those having different compositions but receiving the same heating schedule are placed along the columns.

On careful scrutiny of the electron micrographs, some salient points emerged. So far as the heating schedule is concerned, four points may be mentioned:(i) among samples 


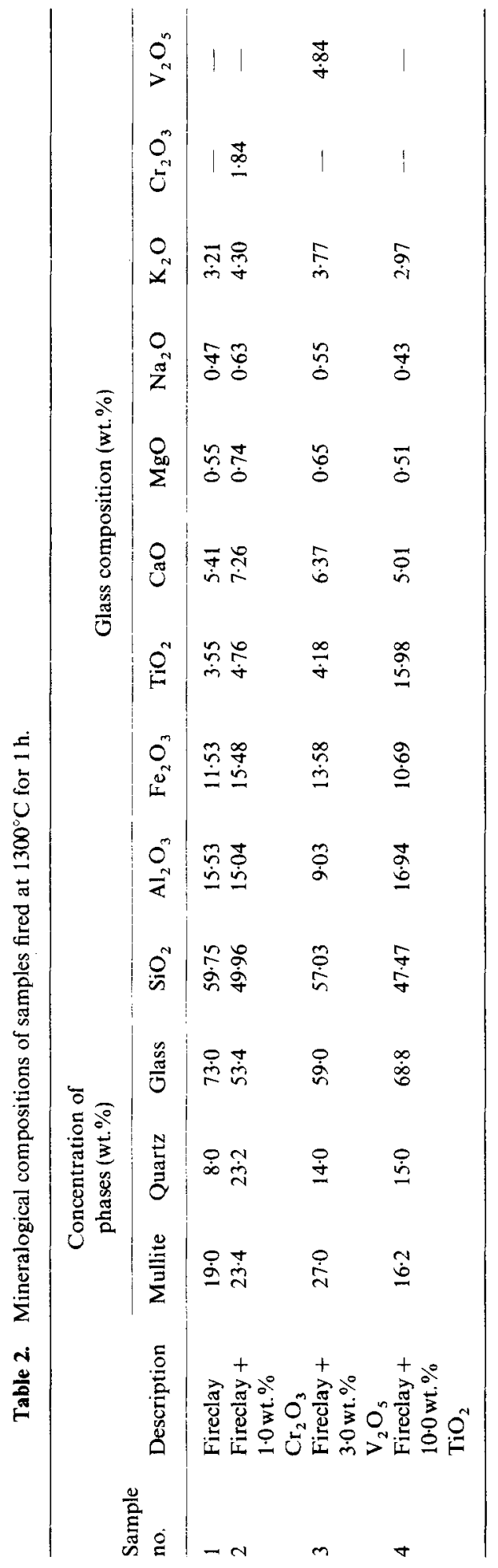




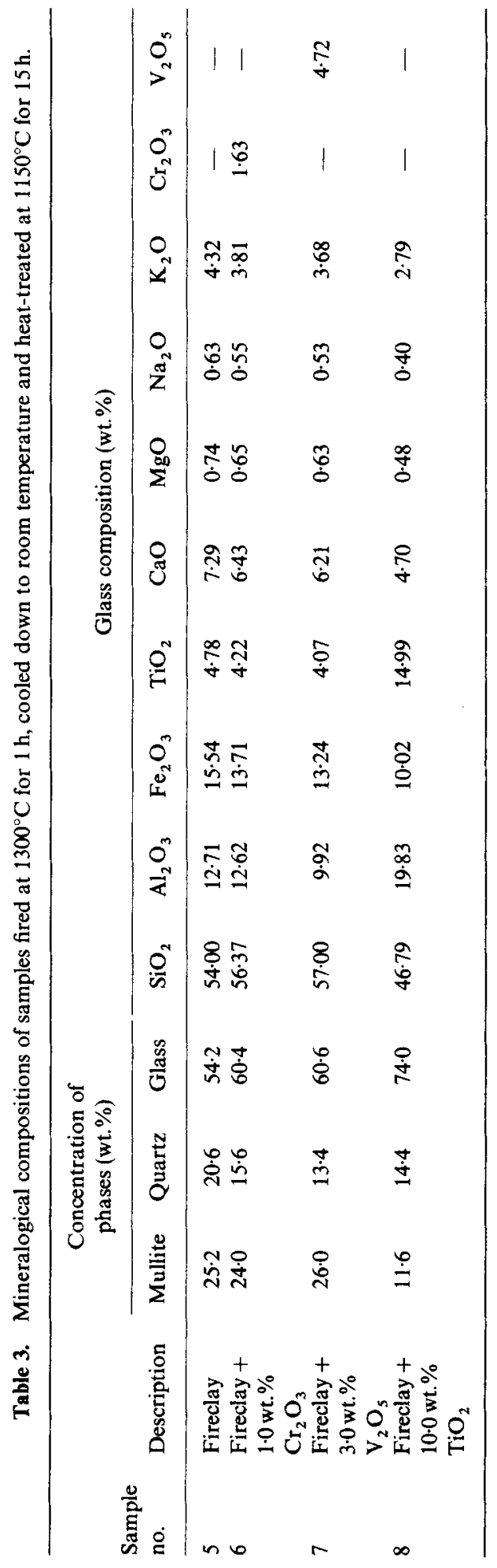




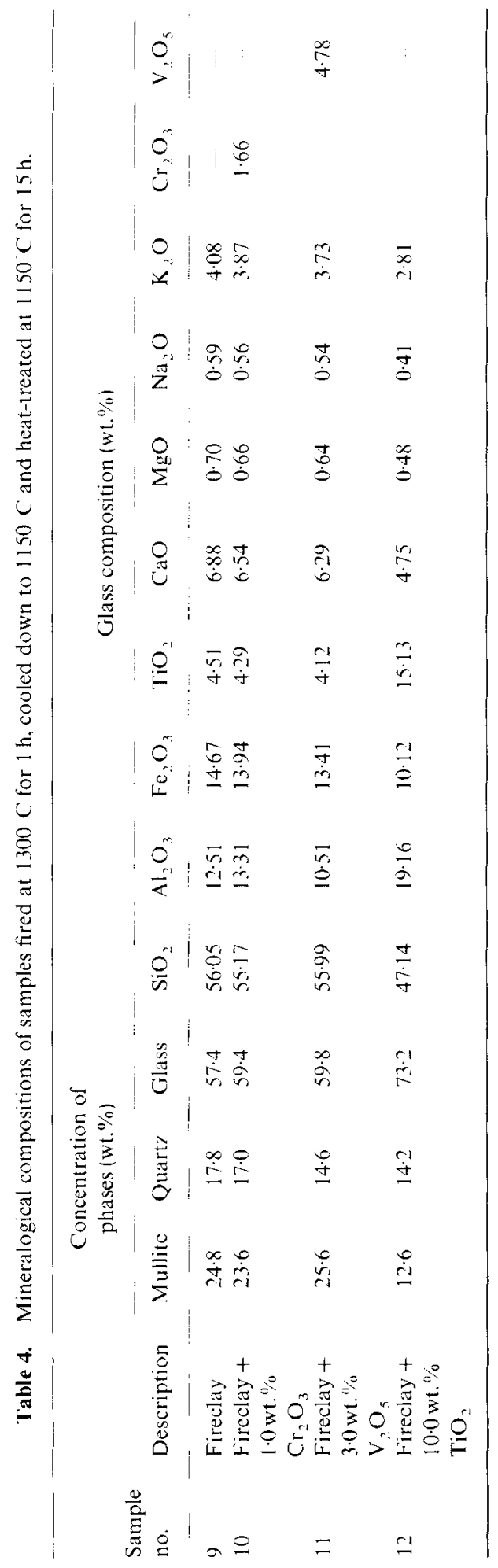



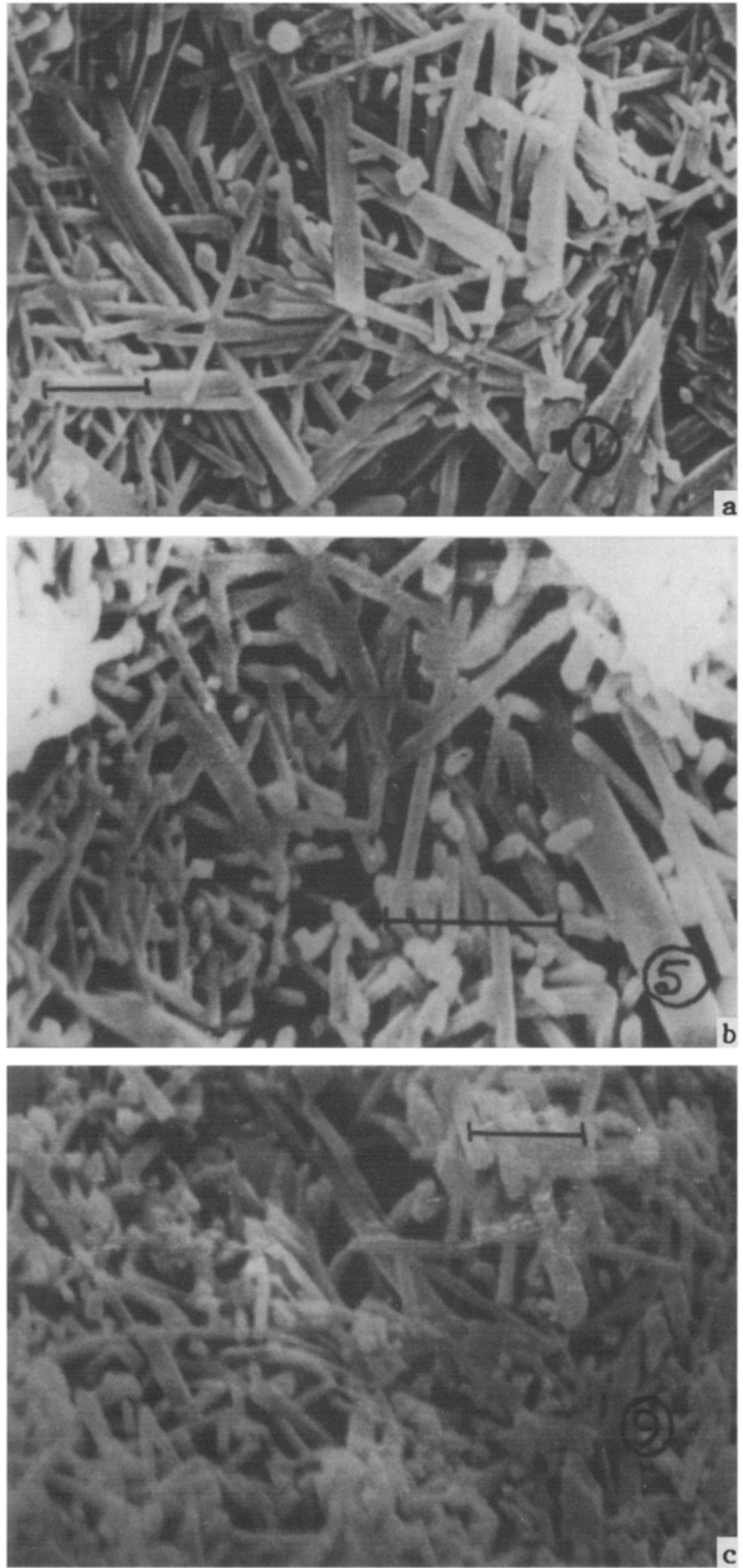

Figure 6. a-c. SEM of samples 1, 5,9 (fireclay only), bar $=1 \mu$. 

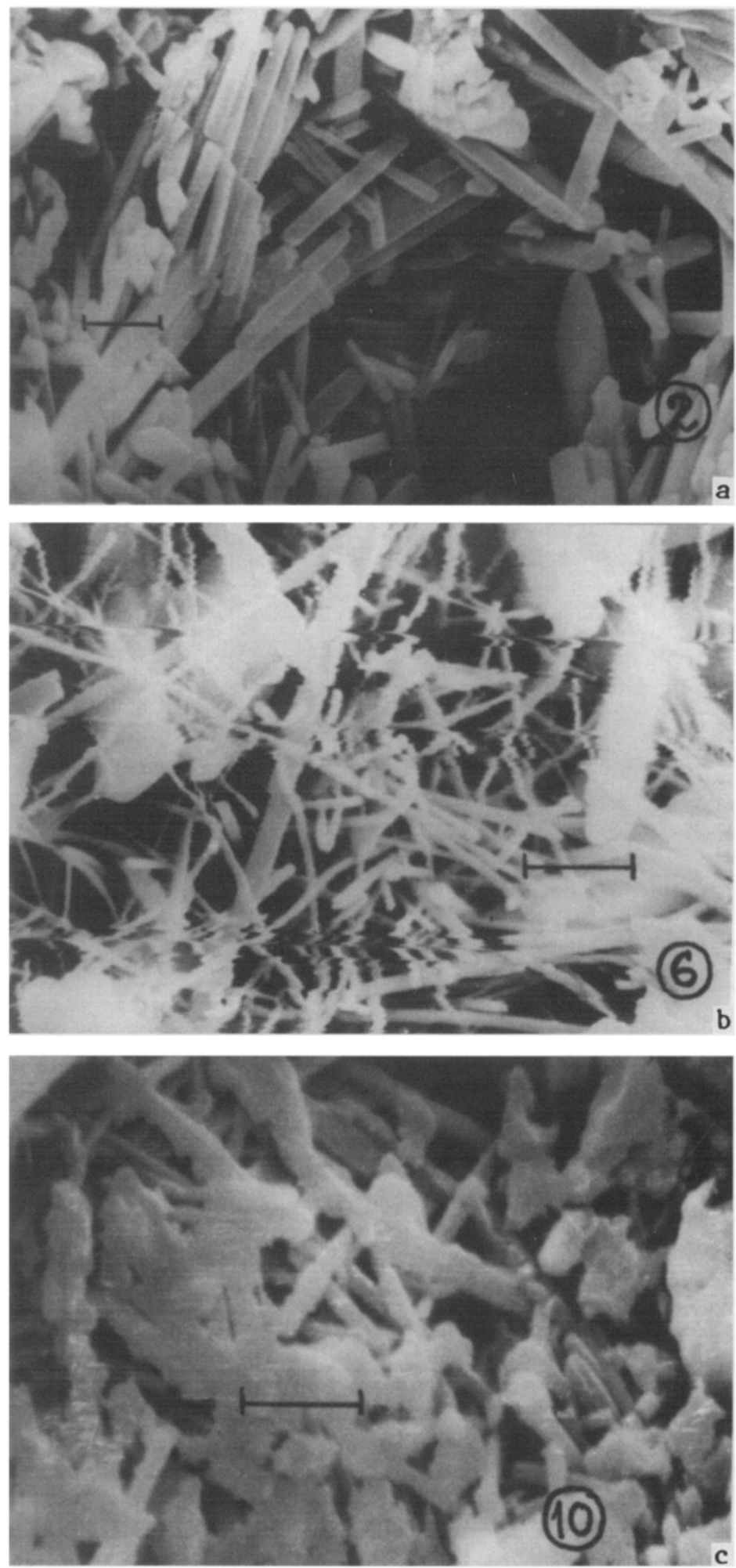

Figure 7. a-c. SEM of samples 2.6, 10 (fireclay $\left.+1.0 \mathrm{wt} . \% \mathrm{Cr}_{2} \mathrm{O}_{3}\right)$, bar $=1 \mu$. 

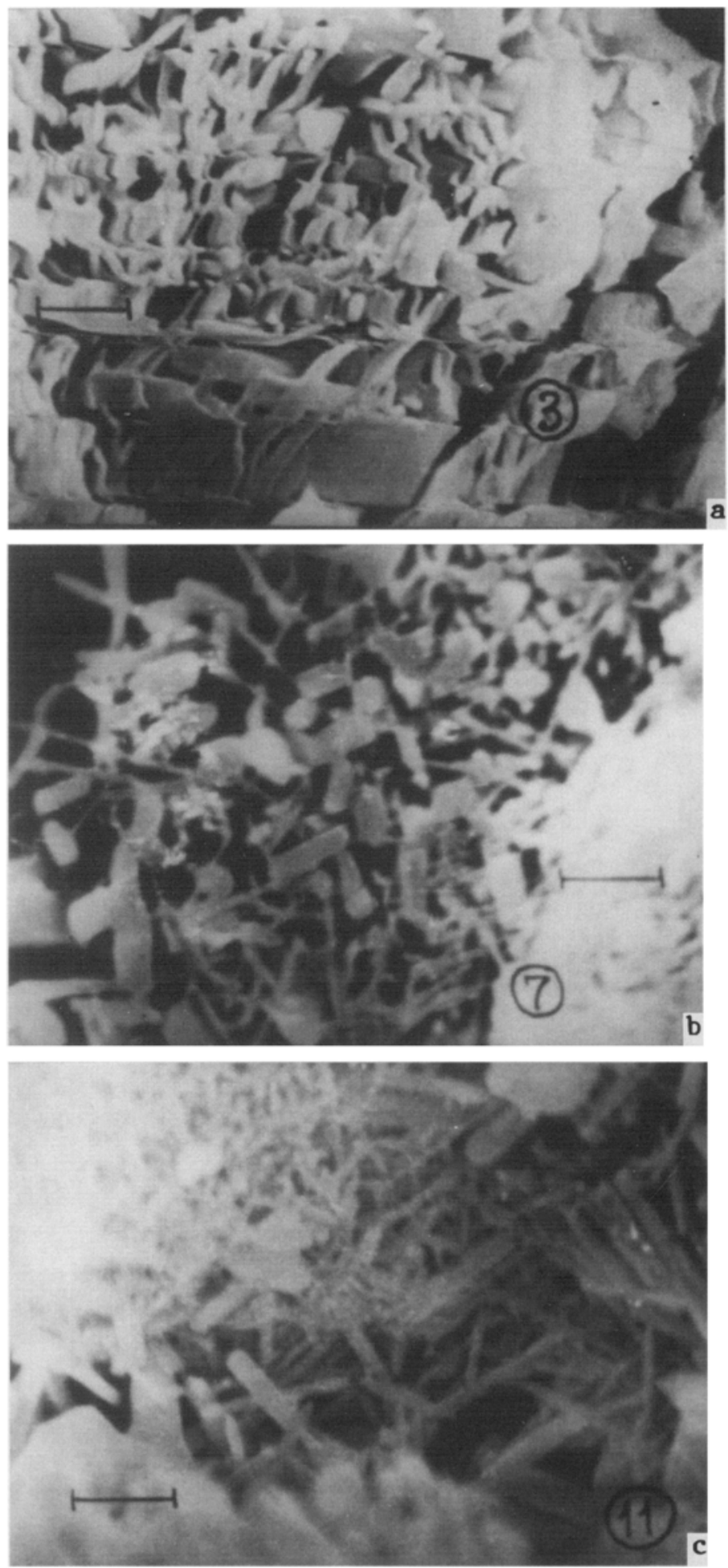

Figure 8. a-c. SEM of samples 3,7.11 (fireclay $+3 \cdot 0 \mathrm{wt} . \% \mathrm{~V}_{2} \mathrm{O}_{5}$ ), bar $=1 \mu$. 

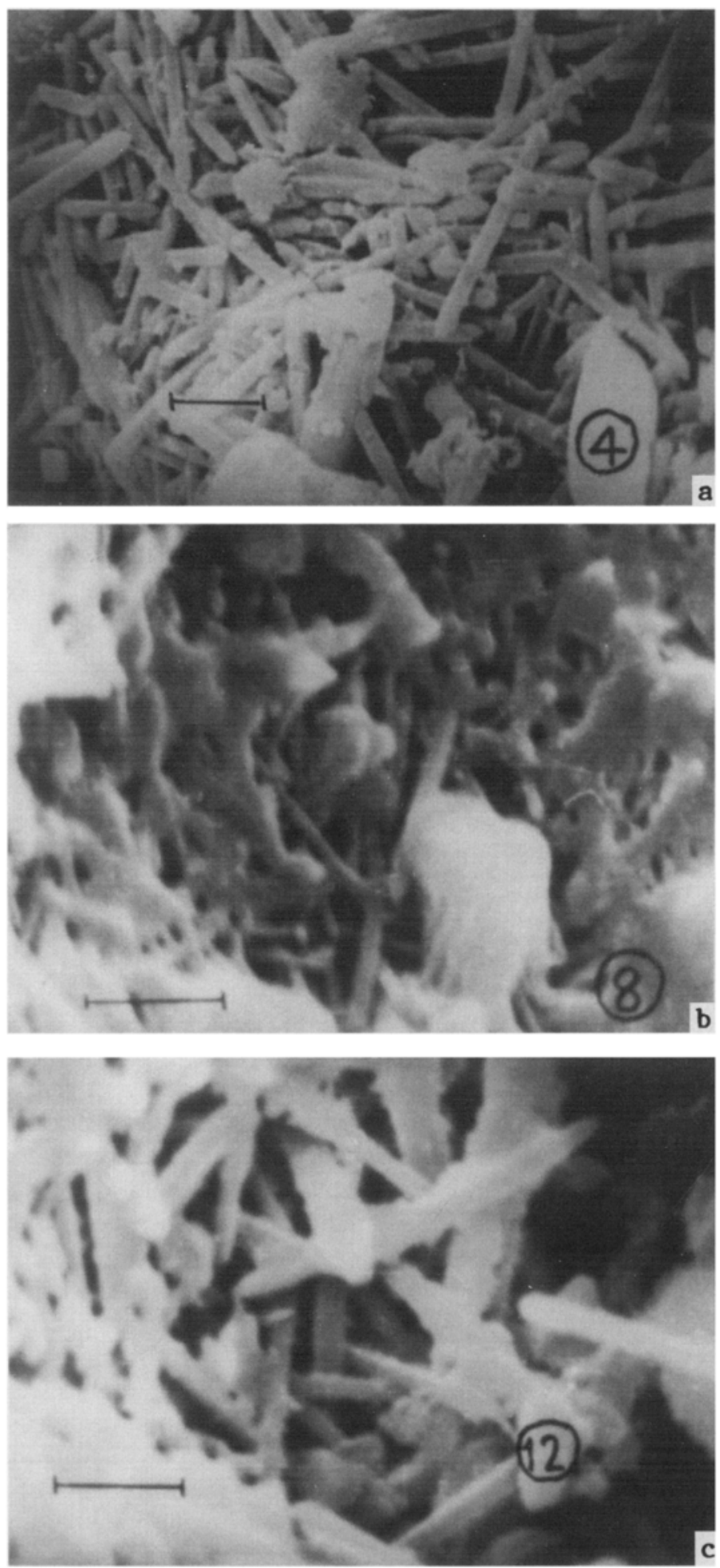

Figure 9. a c. SEM of samples 4, 8, 12 (fireclay $\left.+10-0 \mathrm{wt} . \% \mathrm{TiO}_{2}\right)$ bar $=1 \mu$. 
Table 5. Fireclay refractory samples of different compositions and subjected to different heating schedules.

\begin{tabular}{lll}
\hline \multicolumn{3}{c}{ Sample no. } \\
\hline 1 & 5 & $9 \longrightarrow($ fireclay only $)$ \\
3 & 6 & $10 \longrightarrow\left(\right.$ fireclay $\left.+1.0 \mathrm{wt} . \% \mathrm{Cr}_{2} \mathrm{O}_{3}\right)$ \\
4 & 7 & $11 \longrightarrow\left(\right.$ fireclay $\left.+3 \cdot 0 \mathrm{wt.} \% \mathrm{~V}_{2} \mathrm{O}_{5}\right)$ \\
$\downarrow$ & 8 & $12 \longrightarrow\left(\right.$ fireclay $\left.+10.0 \mathrm{wt} \% \mathrm{TiO}_{2}\right)$ \\
fired at $1300^{\circ} \mathrm{C} / 1 \mathrm{~h}$ & $\begin{array}{l}\text { fired at } 1300^{\circ} \mathrm{C} / 1 \mathrm{~h}, \text { cooled } \\
\text { to room temp., heat-treated } \\
\text { at } 1150^{\circ} \mathrm{C} / 15 \mathrm{~h}\end{array}$ & $\begin{array}{l}1150^{\circ} \mathrm{C}, \text { heat-treated at } \\
1150^{\circ} \mathrm{C} / 15 \mathrm{~h}\end{array}$ \\
\hline
\end{tabular}

1,5 and 9, biggest mullite crystals were observed in sample 1 which was followed by those in samples 5 and 9 , i.e. crystal size decreased from sample 1 to sample 5 to sample 9. But the change between the latter two was comparatively small (figure 6), (ii) among samples 2,6 and 10, biggest mullite crystals were found in sample 2 which was followed by those in samples 6 and 10, i.e. crystal size decreased from sample 2 to sample 6 to sample 10. But the change between the latter two was comparatively small (figure 7), (iii) among samples 3,7 and 11, biggest mullite crystals were found in sample 3 which was followed by those in samples 7 and 11, i.e. crystal size decreased from sample 3 to sample 7 to sample 11. But the change between the latter two was comparatively small (figure 8 ) and (iv) among samples 4, 8 and 12, biggest mullite crystals were identified in sample 4 which was followed by those in samples 8 and 12, i.e. crystal size decreased from sample 4 to sample 8 to sample 12 . But the change between the latter two was comparatively small (figure 9).

It, therefore, appeared from the observations recorded in the above points that the size of mullite crystals was smaller in the samples which were subjected to heattreatment for nucleation and crystallization. Stated otherwise, the heat-treatment leading to crystallization helped develop mullite crystals having size smaller than that obtained by single firing at $1300^{\circ} \mathrm{C}$ for $1 \mathrm{~h}$ only. The scanning electron micrographs also revealed that the distribution of mullite crystals were more uniform in the matrix of the samples which were heat-treated than that in the samples which were not heat-treated.

The microstructure of the samples were, therefore, very much influenced by the firing schedules either through route $(A)$ or route $(B)$. Further, better microstructure could be generated in the fireclay refractories by ceramizing their glassy phase through route (B) or route $(\mathrm{C})$.

With respect to the effect of nucleating agents, it was earlier established (Chaudhuri and Datta 1996b) that $\mathrm{TiO}_{2}$ favoured formation of biggest mullite crystals of highest aspect ratio and reverse was true by employing $\mathrm{V}_{2} \mathrm{O}_{5}$. But $\mathrm{Cr}_{2} \mathrm{O}_{3}$ had intermediate effect.

As it appeared, the effect of the two heat-treatment schedules, e.g. (B) and (C) had very marginal difference on the size of the crystals. So, from the point of view of the large scale or industrial application of this process, schedule (C) seemed better than schedule (B) due to its lower energy requirements. 


\section{Conclusions}

(I) The glassy phase in the poor-grade fireclay refractories could be nucleated and crystallized by incorporating nucleating oxides in the raw fireclay and subjecting it to appropriate heat-treatment schedule.

(II) This process of ceramization of the glassy phase had minor effect on the mineralogical composition but major effect on the microstructure of the samples. Such products were characterized by their uniform microstructure and small crystal size unlike normal products.

(III) The effect of the two heat-treatment schedules (B) and (C) on the constitution of the ceramized fireclay products was almost similar, but the latter would be more appropriate for commercial application owing to its less energy need.

\section{References}

Chaudhuri S P and Datta T 1990 Ceramica Acta 247

Chaudhuri S P and Datta T 1996a Bull. Mater. Sci. 19373

Chaudhuri S P and Datta T 1996b Bull. Mater. Sci. 19383

Hulbert Jr C S 1959 Dana's manual of mineralogy (New York: John Wiley) 17th edn.

Klug H P and Alexander L E 1974 X-ray diffraction procedures for polycrystalline and amorphous materials (New York: John Wiley) 2nd edn.

Macdowell J F and Beall G H $1969 \mathrm{~J}$. Am. Ceram. Soc. 5217

McGee T D 1966 J. Am. Ceram. Soc. 4987

Wells A F 1962 Structural inorganic chemistry (Oxford: Oxford University Press) 3rd edn. 